Monika M. Tyloch

Uniwersytet Mikołaja Kopernika, Toruń

monika_tyloch@o2.pl

\title{
Provedor de Justiça, czyli ochrona praw obywatela $z$ punktu widzenia doświadczeń portugalskich
}

DOI: http://dx.doi.org/10.12775/SIT.2016.026

Po II wojnie światowej wiele państw, nie tylko europejskich, zdecydowało się na wprowadzenie szczególnej instytucji, której podstawowym zadaniem miało być czuwanie nad przestrzeganiem praw obywatelskich. Choć w różnych państwach nosi ona różne nazwy, w literaturze określa się ją również pojęciem ogólnym - ombudsman. Instytucja ta była wprawdzie znana już wcześniej ${ }^{1}$, jednakże masowe łamanie praw człowieka podczas II wojny światowej przekonało większość państw o konieczności ustanowienia takiego szczególnego organu w ich porządkach ustrojowych. Wprowadzenie instytucji ombudsmana miało zapobiec dalszemu łamaniu praw

${ }^{1}$ Instytucja ombudsmana pojawiła się po raz pierwszy w Szwecji w 1709 r., a już niespełna 100 lat później stała się niezależnym organem państwa, wyodrębnionym konstytucyjnie. Podstawową kompetencją kanclerza sprawiedliwości było kontrolowanie działania administracji. W 1919 r. urząd ten został wprowadzony w Finlandii, a w latach 50. XX w. również w Danii. Gwałtowny rozwój instytucji rzecznika w krajach demokratycznych nastąpił w kolejnym 10-leciu (por. Z. Witkowski, A. Bień-Kacała, Prawo konstytucyjne, Toruń 2015, s. 613). 
człowieka, a także zagwarantować obywatelom ochronę praw im przyznanych $^{2}$.

Nie wszystkie państwa, w których zdecydowano się na utworzenie takiego organu, przyjęły model szwedzki ${ }^{3}$. Poszczególne kraje zdecydowały się na wprowadzenie różnych rozwiązań w zakresie kontroli administracji oraz różnych rozwiązań dotyczących ombudsmana jako instytucji uzupełniającej działalność organów państwowych $\mathrm{w}$ zakresie ochrony praw jednostki ${ }^{4}$. Niektóre $z$ państw zdecydowały się na ustanowienie ombudsmana funkcjonującego na szczeblu centralnym, inne natomiast na wprowadzenie instytucji rzecznika działającego jedynie na szczeblu lokalnym. Niektóre $z$ nich wprowadziły instytucję ombudsmana posiadającego ogólne kompetencje, inne zaś ograniczyły jego zakres kompetencji do szczególnej kategorii spraw, np. dotyczących wojska lub dzieci ${ }^{5}$. Co więcej, także rozwiązania w zakresie organizacji wspomnianej instytucji przyjęły różnorodną formę - od organów monokratycznych ${ }^{6}$ do organów kolegialnych ${ }^{7}$. Warto jednak podkreślić, że niektóre instytucje, mimo że noszą nazwę ombudsmana, niekoniecznie pełnią taką funkcję. W literaturze ${ }^{8}$ można spotkać się więc także $z$ instytucją quasi-ombudsmanów.

Provedor de Justiça, czyli Rzecznik Sprawiedliwości, jest portugalskim odpowiednikiem polskiego Rzecznika Praw Obywatelskich. Portugalia zdecydowała się na wprowadzenie instytucji ombudsmana w formie, która dominuje wśród większości państw europejskich ${ }^{9}$.

2 Por. N. Banaszak, Rzecznik Praw Obywatelskich wobec administracji samorzadu terytorialnego, Wrocław 2013, s. 96.

${ }^{3}$ Por. B. Banaszak, Porównawcze prawo konstytucyjne wspótczesnych państw demokratycznych, Warszawa 2012, s. 179.

${ }^{4}$ Por. A. Deryng, Rzecznik Praw Obywatelskich jako wnioskodawca $w$ postępowaniu przed Trybunałem Konstytucyjnym, Warszawa 2014, s. 30.

${ }_{5}$ Por. I. Malinowska, Rzecznik Praw Obywatelskich $w$ systemie ochrony praw i wolności $w$ Polsce, Warszawa 2007, s. 58.

${ }^{6}$ Takie rozwiązanie przyjęto m.in. w Polsce i Portugalii.

7 Takie rozwiązanie przyjęto m.in. w Austrii, Mołdawii, Belgii i Litwie.

8 Por. A. Domańska, Pozycja ustrojowo-prawna Rzecznika Praw Obywatelskich, Łódź 2012, s. 8

9 Por. I. Malinowska, op.cit., s. 58. 
Niniejszy artykuł ma na celu przybliżenie wprowadzonej w Republice Portugalii instytucji Rzecznika Sprawiedliwości, jego kompetencji oraz pozycji ustrojowej, przy szczególnym uwzględnieniu przysługujących mu środków ochrony praw i wolności obywateli w oparciu o obecnie obowiązujące akty prawne. Niniejsza praca ma również zwrócić szczególną uwagę na działalność Rzecznika oraz skuteczność gwarantowanej przez niego ochrony praw przyznanych portugalskim obywatelom.

\section{Pozycja ustrojowa Rzecznika Sprawiedliwości}

Obowiązująca obecnie Konstytucja Portugalii ${ }^{10}$ gwarantuje obywatelom szeroki zakres praw podstawowych i wynikających $z$ nich obowiązków państwa wobec obywateli. Nowelizacje Konstytucji, w tym w szczególności nowelizacja z dnia 3 września 1997 r., wprowadziły nowe procedury sądowe o szybkim i priorytetowym charakterze, których celem stało się umożliwienie obrony praw, wolności oraz gwarancji osobistych obywateli ${ }^{11}$. Procedury te mają jednak jedynie uzupełniać ochronę praw obywatelskich sprawowaną przez Rzecznika Sprawiedliwości.

Provedor de Justiça jest ombudsmanem, organem monokratycznym o kompetencjach ogólnych oraz instytucją usytuowaną centralnie, co oznacza, że swoimi działaniami obejmuje obszar całego państwa, a jego działalność nie jest ograniczona do określonej kategorii spraw ${ }^{12}$. Rzecznik Sprawiedliwości jest organem powołanym do ochrony praw i wolności obywateli, a podstawowym

${ }^{10}$ Konstytucja Republiki Portugalskiej z dnia 2 kwietnia 1976 r., http://libr. sejm.gov.pl/tek01/txt/konst/portugalia-s.html (dostęp: 06.06.2016 r.)

11 Por. J. Miranda, P. Kownacki, Konstytucja Portugalii, Warszawa 2000, s. 30 .

12 Por. L. Garlicki, Ewolucja instytucji Rzecznika Praw Obywatelskich (ombudsmana) $w$ świecie wspótczesnym, w: Rzecznik Praw Obywatelskich, red. L. Garlicki, Warszawa 1989, s. 19. 
celem jego działalności jest urzeczywistnianie podstawowych praw i wolności człowieka ${ }^{13}$.

Wprowadzenie w Portugalii instytucji, której podstawowym zadaniem stała się ochrona praw obywatelskich, było konsekwencją doświadczeń z dyktatorskich rządów Antonia de Oliveira Salazara. Obowiązująca za jego rządów Konstytucja z dnia 11 kwietnia 1933 r. eliminowała wszelkie przejawy liberalizmu, przyznała państwu prawo interwencji i kierowania działalnością gospodarczą, a w konsekwencji doprowadziła do drastycznego ograniczenia podstawowych praw obywateli ${ }^{14}$. Ruch Sił Zbrojnych 25 kwietnia 1974 r. dokonał przewrotu wojskowego, znanego obecne pod nazwą „rewolucji goździków" ${ }^{15}$. Nowa władza zniosła cenzurę oraz przywróciła wolności obywatelskie i polityczne ${ }^{16}$.

Potrzebę utworzenia organu chroniącego prawa obywateli dostrzeżono w Portugalii już we wczesnych latach 70 . XX w. ${ }^{17}$ Zwolennicy wprowadzenia takiej instytucji widzieli potrzebę promowania i ochrony praw człowieka, szczególnie w relacji pomiędzy obywatelem i państwem. W konsekwencji ustawą Nr 212/75 z dnia 21 kwietnia 1975 r. ustanowiono instytucję Rzecznika Sprawiedliwości ${ }^{18}$, a już rok później wprowadzono ją do Konstytucji Republiki Portugalii z dnia 2 kwietnia 1976 r. Konstytucja w sposób nowatorski przyjęła Powszechną deklarację praw człowieka jako kryterium interpretacji praw podstawowych. Potwierdzenie rozwiązań przyjętych przez ustawę w akcie rangi konstytucyjnej miało wzmocnić pozycję Rzecznika oraz podkreślić jego niezależność. Obecnie instytucję Rzecznika Sprawiedliwości reguluje artykuł 23 Konstytucji Portugalii oraz

${ }^{13}$ Por. L.C. Reif, The ombudsman, good governance and the international human rights system, Leiden 2013, s. 141.

14 Por. J. Miranda, P. Kownacki, op.cit., s. 10.

15 Por. A. Łabno-Jabłońska, Od rządów autorytarnych do demokracji parlamentarnej. Rewolucja portugalska 1974-1976, Katowice 1989, s. 22.

${ }^{16}$ Por. eadem, Iberyjska droga do demokracji. Studium prawno-konstytucyjne, Warszawa 1996, s. 20.

17 Por. eadem, Rzecznik Sprawiedliwości $w$ Portugalii, w: Rzecznik Praw Obywatelskich, s. 179.

18 Ustawa ta została uchylona w późniejszym czasie przez ustawę $\mathrm{Nr}$ 81/77 z dnia 22 listopada 1977 r. 
ustawa nr 9/91 z dnia 9 kwietnia 1991 r. ze zmianami ${ }^{19}$, a także ustawa o Biurze Rzecznika Sprawiedliwości i ustawa o dostępie służby wojskowej do Rzecznika Sprawiedliwości.

Konstytucja określa Rzecznika Sprawiedliwości jako organ niezależny, z którym zobowiązane są współpracować organy oraz funkcjonariusze administracji publicznej w celu realizacji jego zadań. Osoba sprawująca funkcję Rzecznika jest powoływana przez Zgromadzenie Republiki ${ }^{20}$ na czas określony w ustawie, tj. cztery lata.

Zgodnie z Konstytucją Rzecznik Sprawiedliwości wybierany jest przez Zgromadzenie Republiki większością dwóch trzecich deputowanych obecnych na posiedzeniu i zarazem większością przewyższającą bezwzględną większość ogólnej liczby deputowanych ${ }^{21}$. Warto przy tym zaznaczyć, że Zgromadzenie Republiki, zgodnie $\mathrm{z}$ art. 164 pkt $\mathrm{m}$ Konstytucji, jest jedynym organem uprawnionym do uchwalania ustaw regulujących instytucję Rzecznika. Ombudsmanem może być jedynie obywatel, który spełnia wymogi dla kandydatów na członka parlamentu, cieszy się ugruntowaną reputacją oraz charakteryzuje się niezależnością. Rzecznik wybierany jest na cztery lata, przy czym może być ponownie wybrany tylko raz, jego stanowisko zaś nie może w żadnym wypadku pozostać nieobsadzone. W przypadku zakończenia kadencji dotychczasowy ombudsman pełni swoją funkcję aż do momentu objęcia urzędu przez nowo wybranego Rzecznika.

Wymagany przymiot niezależności Rzecznika przejawia się przede wszystkim w braku ponoszenia cywilnej oraz karnej odpowiedzialności za wykonywanie swoich zadań, w tym za kierowanie zaleceń, opinii, a także wszelkich innych działan podejmowanych w celu realizacji nałożonych na niego obowiązków. Co więcej, Rzecznik nie

19 Zob. Ustawa o Rzeczniku Sprawiedliwości Nr 9/91 z dnia 9 kwietnia 1991 ze zmianami z dnia 14 sierpnia 1996 (ustawa $\mathrm{Nr}$ 30/96), 10 października 2005 r. (ustawa Nr 52-A/2005) oraz z dnia 18 lutego 2013 r. (ustawa $\mathrm{Nr}$ 17/2013).

${ }^{20}$ Jest to jednoizbowy parlament Portugalii. Zgromadzenie reprezentuje wszystkich obywateli portugalskich i liczy co najmniej 180 i nie więcej niż 230 deputowanych.

${ }^{21}$ Zgodnie $\mathrm{z}$ art. 163 pkt h Konstytucji Portugalii $\mathrm{z}$ dnia 2 kwietnia $1976 \mathrm{r}$. 
może należeć do partii politycznych lub stowarzyszeń, nie może pełnić w nich także żadnych funkcji oraz nie może angażować się w ich publiczną działalność. Funkcja Rzecznika nie może być łączona innymi funkcjami, podobnie jak ma to miejsce w przypadku sędziów sądów powszechnych. Instytucję ombudsmana charakteryzuje stabilność, gdyż Rzecznik jest nieprzenaszalny, co zagwarantowane jest w ustawie Nr 9/91. Gwarancją niezależności omawianej instytucji jest również zakaz zatrzymywania bez zgody parlamentu, $z$ wyjątkiem sytuacji, w których Rzecznik zostanie złapany na gorącym uczynku przestępstwa zagrożonego karą pozbawienia wolności do lat trzech. Ustawa przyznaje mu również wszelkie prawa, przywileje, które przysługują ministrom na podstawie ustawy $\mathrm{Nr} 4 / 85 \mathrm{z}$ dnia 9 kwietnia $1985 \mathrm{r}$.

Zgodnie $z$ art. 23 obowiązującej obecnie Konstytucji Portugalii obywatele mogą wnosić skargi na działanie lub zaniechanie władz publicznych do Rzecznika Sprawiedliwości, który je rozpatruje, jednakże bez prawa do wydawania wiążących rozstrzygnięć, oraz kieruje odpowiednie zalecenia do właściwych organów w celu zapobieżenia naruszeniom lub naprawienia powstałych już naruszeń praw i wolności obywateli.

Ustawa Nr 9/91 z dnia 9 kwietnia 1991 r. rozwija postanowienia Konstytucji regulujące instytucję Rzecznika Sprawiedliwości. Ustawa ta określa podstawowe obowiązki Rzecznika, a pośród nich obronę i promowanie praw, wolności, gwarancji oraz interesów obywateli, celem zapewnienia za pomocą nieformalnych środków sprawiedliwego oraz zgodnego $z$ prawem działania organów publicznych. Ombudsman może również działać jako niezależna narodowa instytucja, której zadaniem jest kontrolowanie implementacji umów międzynarodowych oraz konwencji o prawach człowieka, jeżeli zostanie mu wyznaczone takie zadanie. Rzecznik Sprawiedliwości jest obowiązany rozwijać współpracę $z$ odpowiadającymi mu instytucjami na świecie, Unią Europejską oraz międzynarodowymi organizacjami dla wspierania oraz promowania praw, wolności i gwarancji obywateli. Przy wypełnianiu swoich zadań Rzecznik jest całkowicie niezależny. 


\section{Zadania i uprawnienia Rzecznika Sprawiedliwości}

Działania Rzecznika koncentrują się w głównej mierze na kontroli działalności organów centralnych, regionalnych lub lokalnej administracji, Sił Zbrojnych, instytucji publicznych, publicznych przedsiębiorstw lub przedsiębiorstw, w których większość kapitału należy do państwa, koncesjonariuszy zajmujących się publicznymi usługami lub wykorzystujących własność państwową, publicznych zrzeszeń, a także prywatnych jednostek wykonujących zadania publiczne w zakresie przestrzegania praw obywateli ${ }^{22}$. W wyjątkowych sytuacjach zakres działalności Rzecznika może również obejmować relacje między osobami fizycznymi, jeśli dotyczy ochrony praw, wolności i gwarancji obywateli ${ }^{23}$.

Do podstawowych kompetencji Rzecznika Sprawiedliwości należy zaliczyć przede wszystkim kierowanie zaleceń do odpowiednich organów w celu uchylenia skutków niezgodnego $\mathrm{z}$ prawem lub niesprawiedliwego działania organów władzy publicznej lub dla poprawy świadczonych przez nich usług i stosowanych procedur. Nadto do zadań Rzecznika należy wskazywanie braków w legislacji oraz kierowanie zaleceń w celu interpretacji niejasnych norm, zmiany lub unieważnienia norm naruszających prawa obywateli, a także kierowanie do Przewodniczącego Parlamentu, Premiera oraz bezpośrednio do zainteresowanych ministrów sugestii co do projektów aktów prawnych. Wszelkie zalecenia kierowane do parlamentu oraz do ciał ustawodawczych regionów autonomicznych muszą być publikowane w odpowiednich dziennikach urzędowych.

Do zadań Rzecznika należy także formułowanie opinii, na żądanie parlamentu, dotyczących spraw związanych $z$ jego kompetencjami. Rzecznik zobowiązany jest również do promowania ochrony fundamentalnych praw oraz wolności, a także do informowania obywateli o przysługujących im prawach i srodkach służących im do ich ochrony.

\footnotetext{
${ }^{22}$ Por. L. Garlicki, op.cit., s. 20.

${ }^{23}$ Zgodnie $z$ art. 2 ustawy $\mathrm{Nr}$ 9/91 z dnia 9 kwietnia $1992 \mathrm{r}$.
} 
Rzecznik Sprawiedliwości może żądać także stwierdzenia przez Sąd Konstytucyjny niekonstytucyjności lub niezgodności z prawem jakiekolwiek normy prawnej wynikającej $z$ aktu ustawodawczego posiadającego moc powszechnie obowiązującą, również $z$ powodu naruszenia hierarchii aktów prawnych ${ }^{24}$. Żądanie stwierdzenia przez Sąd Konstytucyjny niekonstytucyjności lub niezgodności z prawem może również dotyczyć normy prawnej aktu regionalnego $z$ powodu naruszenia statutu regionu lub ustawy Republiki lub jakiekolwiek normy prawnej uchwalonej przez organ, a wynikającej z naruszenia praw jednego $z$ regionów wynikających $z$ jego statutu ${ }^{25}$. Na wniosek Rzecznika portugalski Sąd Konstytucyjny bada również i stwierdza naruszenie Konstytucji w sytuacji niepodjęcia środków ustawodawczych koniecznych do zastosowania norm konstytucyjnych. Wniosek taki złożyć może również Prezydent Republiki, a także w przypadku naruszenia praw regionów autonomicznych przewodniczący regionalnych zgromadzeń ustawodawczych ${ }^{26}$.

Warto przy tym wspomnieć, że wykonywanie obowiązków Rzecznika nie może być powierzone osobom trzecim. Wyjątkiem są jednak sytuacje takie jak śmierć Rzecznika, jego nieodwracalna fizyczna niepełnosprawność lub niespełnienie przez niego niezbędnych warunków do pełnienia funkcji Rzecznika. Co więcej, wykonywanie zadań ombudsmana przez osoby trzecie może mieć także miejsce $\mathrm{w}$ razie złożenia przez Rzecznika rezygnacji ze sprawowania funkcji lub powstania innych przeszkód uniemożliwiających sprawowanie powierzonych mu funkcji. Rzecznik może także w każdym czasie powołać i odwołać dwóch zastępców wybranych spośród osób wyróżniających się odpowiednim wykształceniem, odpowiednią reputacją oraz niezależnością adekwatną do przymiotu niezależności wymaganej dla kandydatów ubiegających się o stanowisko Rzecznika. W przypadku, gdy zostaną powołani zastępcy, Rzecznik

${ }^{24}$ Righting wrongs. The ombudsman in six continents, red. R. Gregory, P. Giddings, Amsterdam 2000, s. 451.

${ }^{25}$ Zgodnie $z$ art. 281 Konstytucji Portugalii $z$ dnia 2 kwietnia 1976 r.

${ }^{26}$ Jest to tzw. badanie niekonstytucyjności wynikającej z zaniechania. W sytuacji, gdy Sąd Konstytucyjny stwierdzi niekonstytucyjność przez zaniechanie, informuje o tym właściwy organ ustawodawczy. Zob. art. 283 Konstytucji Portugalii z dnia 2 kwietnia 1976 r. 
może przekazać jednemu z nich swoje obowiązki z zakresu ochrony praw dzieci.

Oprócz swoich podstawowych kompetencji portugalski Rzecznik Sprawiedliwości jest od 1999 r. NHRI, tj. Narodową Instytucją Praw Człowieka ${ }^{27}$, która promuje i broni fundamentalnych praw człowieka przed wszelkimi formami agresji, nie tylko ze strony organów państwowych. Rzecznik Sprawiedliwości wchodzi również w skład Rady Państwa Portugalii, to jest politycznego organu doradczego Prezydenta Republiki. Radzie Państwa przewodniczy Prezydent Republiki, a do jej składu należą, oprócz Rzecznika, Przewodniczący Zgromadzenia Republiki, Premier, Przewodniczący Sądu Konstytucyjnego, przewodniczący rządów regionalnych, byli Prezydenci Republiki, wybrani w okresie obowiązywania konstytucji, o ile nie zostali złożeni z urzędu, pięciu obywateli wyznaczonych przez Prezydenta Republiki na okres trwania jego kadencji oraz pięciu obywateli wybranych przez Zgromadzenie Republiki, zgodnie z zasadą proporcjonalności, na okres kadencji parlamentu ${ }^{28}$. Do kompetencji Rady Państwa należy przede wszystkim wydawanie opinii w sprawie rozwiązania Zgromadzenia Republiki i organów władzy w regionach autonomicznych, wyrażanie opinii w sprawie powoływania i odwoływania Ministrów Republiki w regionach autonomicznych, a także wyrażanie opinii w sprawie wypowiadania wojny i zawierania pokoju ${ }^{29}$.

Działalność Rzecznika Sprawiedliwości nie ogranicza się jedynie do obrony praw obywateli w granicach państwa. Swoje zadania Rzecznik wykonuje poprzez członkostwo w wielu międzynarodowych organizacjach i ciałach o międzynarodowym oraz regionalnym zakresie działania tworzonych w większości przez Unię Europejską, Narody Zjednoczone, Wspólnotę Państw Portugalskojęzycznych. W konsekwencji Rzecznik jest członkiem ICC ${ }^{30}$, organizacji, która bierze odpowiedzialność za akredytację NHRI. Bierze także czynny

27 Ang. The National Human Rights Institution.

${ }^{28}$ Zob. art. 142 Konstytucji Portugalii z dnia 2 kwietnia 1976 r.

${ }^{29}$ Zob. art. 145 Konstytucji Portugalii z dnia 2 kwietnia 1976 r.

30 Ang. The International Coordinating Committee of National Institutions for the Promotion and Protection of Human Rights. 
udział w Europejskiej Sieci NHRI. Działalność międzynarodowa Rzecznika przejawia się też we współpracy z partnerskimi instytucjami, których celem jest wzmocnienie praw człowieka, w tym także z Wysokim Komisarzem Narodów Zjednoczonych ds. Praw Człowieka ${ }^{31}$.

\section{Postępowanie w przypadku naruszenia praw obywateli}

Zgodnie $z$ art. 3 ustawy Nr 9/91 z dnia 9 kwietnia 1991 r. zarówno osoby fizyczne, jak i osoby prawne mogą wnieść do Rzecznika Sprawiedliwości skargę na działanie lub zaniechanie organów publicznych. Rzecznik analizuje wniesioną skargę, a w przypadku, gdy uzna, iż w rzeczywistości doszło do naruszeń praw obywateli, podejmuje działania, których celem jest zapobiegnięcie dalszym naruszeniom praw i wolności.

Rzecznik może również działać z własnej inicjatywy, na podstawie informacji uzyskanych m.in. za pośrednictwem mediów. Taką możliwość przewidują art. 4 oraz $24 \S 1$ ustawy Nr 9/91. Czynności podejmowane przez Rzecznika $z$ własnej inicjatywy mają na celu ochronę i promowanie praw, wolności, gwarancji oraz interesów obywateli, w szczególności tych dotyczących wieku, rasy, pochodzenia etnicznego, płci czy też niepełnosprawności. Rzecznik może podejmować działania niezależnie od administracyjnych lub sądowych środków ochrony praw obywateli zapewnionych przez Konstytucję oraz ustawy. W większości jednak spraw podstawą działania ombudsmana jest otrzymana skarga.

W swoich działaniach Rzecznik ma pełną dowolność. Po podjęciu sprawy może przeprowadzić dochodzenie, monitorować, zawiadamiać odpowiednie organy o powstałych nieprawidłowościach, a także kierować do odpowiednich organów zalecenia, w tym także rekomendować zmiany w działaniu organów dla właściwego przestrzegania praw człowieka.

${ }^{31}$ http://www.provedor-jus.pt/?idc=92 (dostęp: 06.06.2016 r.) 
W sytuacji gdy obywatel ma poczucie, że przyznane mu prawa zostały naruszone lub gdy czuje, że został pokrzywdzony przez niesprawiedliwe albo niezgodne $z$ prawem działanie władz publicznych lub jednostek prywatnych, które wykonywały zadania publiczne, może wnieść skargę do Rzecznika Sprawiedliwości. W skardze tej musi dokładnie określić stan faktyczny oraz przyczynę wniesienia skargi. Warto przy tym podkreślić, że możliwość wniesienia skargi do Rzecznika podlega ograniczeniom podmiotowym w odniesieniu do członków sił zbrojnych oraz organów państwa i instytucji ${ }^{32}$.

Skargi mogą przybierać zarówno formę ustną, jak i pisemną. Nadto muszą zawierać dane osoby wnoszącej skargę oraz jej adres, a także jeśli to możliwe, jej podpis. Nie muszą jednak spełniać innych wymogów właściwych dla pism procesowych ${ }^{33}$. Skarga może być przesłana do Rzecznika listem, faksem, e-mailem lub na specjalnym formularzu, może być także złożona osobiście w Biurze Rzecznika.

Podejmując sprawę w celu wykonania nałożonych na niego obowiązków, ombudsman może przeprowadzić kontrolę w organach, których działanie stało się przedmiotem skargi, przy czym kontrola ta może odbyć się także bez uprzedniego zawiadomienia. Kontrole działalności mogą być przeprowadzone w organach władzy publicznej na szczeblu centralnym, regionalnym oraz lokalnym, włączając w to także cywilne oraz wojskowe więzienia, przedsiębiorstwa, a także inne jednostki niezależnie od ich stanu prawnego, a także inne podmioty, których działalność pozostaje pod kontrolą Rzecz-

${ }^{32}$ Zgodnie $z$ przepisami ustawy Nr 19/95, z dnia 13 lipca 1995 r. oraz przepisami ustawy o Obronie Narodowej żołnierz przed wniesieniem indywidualnej skargi do Rzecznika Sprawiedliwości musi wykorzystać wszystkie przysługujące mu środki odwoławcze. Warto jednak w tym miejscu wspomnieć, że zgodnie z wyrokiem Sądu Konstytucyjnego Nr 404/2012 z dnia 18 września 2012 r. norma zawarta w art. $34 \S 1$ ustawy o Obronie Narodowej została uznana za niekonstytucyjną $z$ uwagi na nieusprawiedliwione ograniczenie możliwości złożenia skargi do Rzecznika Sprawiedliwości. W drugim natomiast przypadku organy publiczne nie mogą złożyć skargi na inne organy o tym samym charakterze, z uwagi na rolę instytucji rzecznika - Rzecznik ma bronić prawa obywateli przed naruszeniami władzy publicznej, a nie rozstrzygać konflikty między organami (http: / /www.provedor-jus.pt/?idc=92, (dostęp: 06.06.2016 r.).

${ }^{33}$ Por. L. Garlicki, op.cit., s. 22. 
nika. W czasie kontroli Rzecznik Sprawiedliwości może przesłuchiwać osoby pełniące funkcje w kontrolowanych organach i urzędach, a także pozyskiwać od nich informacje oraz dokumenty, jeżeli tylko zajdzie taka potrzeba. Co więcej, Rzecznik może podjąć postępowanie wyjaśniające, jeśli uzna to za konieczne, w celu zebrania materiału dowodowego. Ustawa przyznaje Rzecznikowi uprawnienie do skorzystania ze wszystkich przysługujących mu środków, $z$ wyłączeniem jedynie tych, które mogą skutkować ograniczeniem prawa obywateli. Rzecznik Sprawiedliwości może również współpracować $z$ odpowiednimi organami i urzędami w celu wypracowania rozwiązań zapewniających jak najlepszą ochronę praw i interesów obywateli, a także wpływających na polepszenie standardu działań podejmowanych przez organy administracji państwowej.

Trzeba jednak zauważyć, iż działalność Rzecznika Sprawiedliwości doznaje istotnych ograniczeń ustanowionych w ustawie Nr 9/91. Rzecznikowi nie przysługuje ani prawo do unieważniania, ani uchylania lub modyfikowania decyzji organów władzy publicznej, a jego interwencje nie mogą prowadzić do zawieszenia biegu terminów wyznaczonych przez orzeczenia administracji lub sądów ${ }^{34}$. Co więcej, ani działalność suwerennych organów, ani organów rządowych Regionów Autonomicznych nie może być przedmiotem kontroli Rzecznika. Wyjątkiem jest jedynie ich działalność administracyjna oraz akty wykonywane pod nadzorem administracji publicznej. Przedmiotem skargi nie może być również działalność orzecznicza sądów ${ }^{35}$.

W wypełnianiu swoich zadań Rzecznik Sprawiedliwości ściśle współpracuje $z$ parlamentem. Corocznie do 30 kwietnia Rzecznik jest zobowiązany przekazać parlamentowi raport o podjętych przez siebie działaniach, inicjatywach, otrzymanych skargach, podjętych postępowaniach oraz ich wynikach. Raport Rzecznika jest podawany również do publicznej wiadomości i publikowany w dzien-

${ }^{34}$ Podobne rozwiązanie przyjęte zostało w ustawie $\mathrm{Nr} 81 / 77 \mathrm{z}$ dnia 22 listopada 1977 r. (por. L. Garlicki, op.cit., s. 23).

35 Podobne rozwiązanie przyjęte zostało w ustawie Nr 81/77 z dnia 22 listopada 1977r. (Por. A. Łabno-Jabłońska, Rzecznik Sprawiedliwości w Portugalii, s. 187). 
niku urzędowym parlamentu. Rzecznik może także uczestniczyć w pracach komisji parlamentarnych, które zajmują się sprawami wchodzącymi w zakres jego zainteresowania. Warto również wspomnieć, że parlament, komisje parlamentarne oraz ich członkowie mogą wysłuchać Rzecznika oraz zwrócić się do niego o powzięcie odpowiednich kroków przy rozpatrywaniu skarg i petycji wniesionych bezpośrednio do tych organów.

Skarga wniesiona do Rzecznika Sprawiedliwości może być skargą wniesioną przez jedną osobę, jak również przez grupę obywateli. Przysługuje obywatelom w każdym czasie. Ani Konstytucja, ani ustawy nie określają terminu do jej wniesienia.

Po wniesieniu skargi Rzecznik dokonuje w pierwszej kolejności wstępnej jej kontroli, w której sprawdza dopuszczalność jej wniesienia. Natychmiastowe odrzucenie skargi może być spowodowane m.in. niemożnością zidentyfikowania skarżącego, gdy jest to niezbędne do rozpatrzenia sprawy, wniesieniem skargi w złej wierze lub w sposób oczywiście bezzasadny oraz wniesieniem skargi, której przedmiotem są sprawy spoza zakresu kompetencji Rzecznika. Decyzja o wszczęciu postępowania lub odrzucenie skargi po wstępnej kontroli musi być podana do wiadomości skarżącego.

Po przyjęciu skargi do rozpoznania Rzecznik przeprowadza postępowanie wyjaśniające, które w głównej mierze polega na zwracaniu się do odpowiednich organów o udzielenie informacji, a następnie przeprowadzaniu kontroli w celu ustalenia stanu faktycznego. W czasie kontroli przeprowadza się badania, inspekcje, przesłuchania, śledztwo, a także inne uzasadnione w konkretnych przypadkach procedury, które jednak w żaden sposób nie mogą naruszyć fundamentalnych praw obywateli. Srodki przedsiębrane przez Rzecznika winny być odpowiednie i nie powinny powodować zbędnej zwłoki. Warto jednak zauważyć, że środki te mogą być podejmowane nie tylko przez ombudsmana osobiście, ale również przez jego Biuro, a także organy prokuratury lub inne wskazane jednostki, jeśli tylko zajdzie taka potrzeba.

Kontrolowane jednostki mają natomiast obowiązek przekazywania Rzecznikowi wszelkich niezbędnych informacji, przygotowywania dokumentów do kontroli, a także przekazywania ich Rzecznikowi, jeśli zajdzie taka potrzeba. Co więcej, Rzecznik jest uprawniony do 
żądania złożenia oświadczenia lub informacji przez obywateli, jeśli jest to niezbędne dla ustalenia stanu faktycznego.

Wniesiona skarga podlega oddaleniu, jeśli dotyczy materii spoza zakresu kompetencji Rzecznika, jeśli zostanie uznana za bezzasadną lub gdy nie ma wystarczających podstaw do wszczęcia postępowania. Oddaleniu podlega również skarga na niezgodność z prawem lub niesprawiedliwość, gdy szkoda wyrządzona przez naruszenie została już naprawiona. Trzeba wspomnieć, że również w takich sytuacjach informacja o oddaleniu skargi musi być podana do wiadomości skarżącego.

Ombudsman może przekazać skierowaną do niego skargę do innych odpowiednich organów według właściwości sprawy, jeśli skarżącemu przysługują środki sądowe lub administracyjne zagwarantowane przez prawo. Niezależnie od powyższego Rzecznik jest obowiązany poinformować skarżącego o wszelkich środkach ochrony praw, które mu przysługują. W przypadkach mniejszej wagi, przy jednorazowych naruszeniach praw obywateli, Rzecznik może poprzestać na skierowaniu uwag i zaleceń do organu lub urzędu, którego działanie było przedmiotem skargi lub też skargę oddalić i zakończyć sprawę po wysłuchaniu wyjaśnień organu. Trzeba przy tym podkreślić, że Rzecznik przed wydaniem jakiegokolwiek zalecenia jest obowiązany taki organ wysłuchać.

Jeśli zebrany w postępowaniu materiał dowodowy wskazuje na naruszenie przepisów karnych lub dyscyplinarnych danego organu, Rzecznik zobowiązany jest poinformować o tym naruszeniu Prokuratora Generalnego lub właściwy organ nadrzędny. Natomiast jeżeli po przeprowadzeniu postępowania Rzecznik dojdzie do wniosku, że skarga złożona została w złej wierze, sprawa zostanie przekazana odpowiedniej prokuraturze celem wszczęcia postępowania karnego i w konsekwencji pociągnięcia skarżącego do odpowiedzialności.

Co istotne, działania Rzecznika i wydawane przez niego decyzje nie mogą być przedmiotem zaskarżenia. Wszelkie zastrzeżenia co do wykonywanych zadań kierowane mogą być bezpośrednio do ombudsmana. Wyjątkiem jest jednak możliwość zaskarżenia przyznana przez ustawodawcę w art. 44 ustawy Nr 9/91, dotycząca decyzji wydawanych w związku z zarządzaniem Biurem Rzecznika. 
Decyzje te mogą być zaskarżane do portugalskiego Najwyższego Sądu Administracyjnego.

Gdy zebrany w sprawie materiał dowodowy jednoznacznie wskazuje na naruszenie praw i wolności obywateli lub niezgodne $z$ prawem działanie organów, Rzecznik może skierować do odpowiedniego organu zalecenia. Rekomendacje kierowane są do organu, któremu przysługuje możliwość naprawienia niezgodnego z prawem lub niesprawiedliwego działania organu lub naprawienia konsekwencji takiego działania. Organ, do którego skierowane zostaną zalecenia, jest obowiązany poinformować Rzecznika o swoim stanowisku w sprawie w okresie 60 dni od ich otrzymania. Niezastosowanie się do zaleceń Rzecznika musi być należycie uzasadnione. W sytuacji, gdy zalecenia nie będą wykonane przez organ, Rzecznik może zwrócić się do organu go nadzorującego lub ministra kierującego danym działem administracji rządowej. Jeśli organ wykonawczy lokalnej rady nie wypełni zalecenia, Rzecznik może skierować sprawę pod jej obrady. Wszelkie decyzje oraz podejmowane przez ombudsmana działania winny być podane do wiadomości organów, urzędników, na których działania została wniesiona skarga, oraz skarżącego. Istotne jest, że działania podejmowane przez Rzecznika wszczęte na podstawie skargi nie podlegają opłacie i nie wymagają przymusu adwokackiego. Trzeba również podkreślić, iż ustawa Nr 9/91 nakłada na wszystkie organy władzy publicznej obowiązek pomocy Rzecznikowi przy wykonywaniu powierzonych mu zadań ${ }^{36}$.

Instytucja Rzecznika Sprawiedliwości działa w Portugalii już od 41 lat, a jej istotna pozycja nadal pozostaje niezmienna. Zauważyć można jednak w ostatnim czasie zmniejszenie liczby spraw przez niego rozpatrywanych. W 2012 r. Rzecznik skierował do organów państwowych aż 35 rekomendacji, w 2013 r. 12, rok później osiem, a w 2015 r. dziewięć rekomendacji. Do czerwca 2016 r. Rzecznik Sprawiedliwości skierował do organów jedynie dwie rekomenda$\mathrm{cje}^{37}$. Przez cały okres istnienia instytucji Rzecznik skierował aż 54 wnioski o sprawdzenie niekonstytucyjności lub niezgodności

${ }^{36}$ Taki obowiązek przewidziany został w art. 19 oraz 29 ustawy $\mathrm{Nr}$ 9/91 z dnia 9 kwietnia $1991 \mathrm{r}$.

${ }^{37}$ http://www.provedor-jus.pt/?idc=67\&dta=2015 (dostęp: 6.06 .2016 r.) 
z prawem norm prawnych ${ }^{38}$. Zwrócić należy jednak uwagę na fakt, iż postępowanie podejmowane przez Rzecznika Sprawiedliwości z własnej inicjatywy stanowi jedynie niewielki wycinek wszystkich rozpatrywanych spraw. Analiza sprawozdań kierowanych do Zgromadzenia Republiki prowadzi do stwierdzenia, że w całym okresie działalności Rzecznika przeważają skargi wniesione przez podmioty indywidualne. W latach ubiegłych dało się zaobserwować tendencje do wzrostu liczby skarg wnoszonych przez obywateli. W 2012 r. wpłynęło do Rzecznika 7015 skarg, aż o 1215 więcej w porównaniu $z$ rokiem poprzednim ${ }^{39}$. Najwięcej skarg dotyczyło spraw związanych z zabezpieczeniem społecznym, zatrudnieniem, podatkami oraz administracją wymiaru sprawiedliwości. W 2013 r. wniesiono już 8512 skarg, a w 2014 r. o sześć skarg więcej. Natomiast w 2015 r. liczba skarg spadła do $7329^{40}$. Podobnie jak w latach poprzednich, w ubiegłym roku większość skarg wniesionych do Rzecznika zostało rozpatrzonych w ciągu 30 dni. Warto zauważyć, że aż 91\% wniesionych spraw zakończono w czasie do jednego roku, a jedynie $1 \%$ spraw został rozpatrzony w czasie powyżej 2 lat. Większość spraw z 2015 r. pochodzących ze skarg, tj. 66,1\%, rozpatrzono do końca roku kalendarzowego. $\mathrm{W}$ porównaniu $\mathrm{z}$ rokiem poprzednim stanowi to spadek o 2 punkty procentowe ${ }^{41}$. Analogicznie do lat poprzednich, główną przyczyną wniesienia skarg było naruszenie praw związanych z zabezpieczeniem społecznym (19,5\%), podatkami (15,7\%), zatrudnieniem $(11,6 \%)$ oraz administracją wymiaru sprawiedliwości (7,6\%). Pomimo zauważalnego spadku liczby spraw, które wpłynęły do Rzecznika Sprawiedliwości w 2015 r., należy zauważyć, iż

38 http://www.provedor-jus.pt/?idc=90 (dostęp: 6.06.2016 r.)

39 Raport Rzecznika Sprawiedliwości skierowany do Parlamentu, Portuguese Ombudsman. Report to the Parliament 2012. Summary, Lisbon 2013, s. 18 (http://www.provedor-jus.pt/?idc=16, dostęp: 6 czerwca 2016 r.).

${ }^{40}$ Raport Rzecznika Sprawiedliwości skierowany do Parlamentu, Provedorde Justica Instituicao Nacional De Dereitos Humanos Relatorio a Assembleia sa Republica, Lisboa 2015, s. 18, (http://www.provedor-jus.pt/?idc=16, dostęp: 06.06.2016 r.).

${ }^{41}$ Raport Rzecznika Sprawiedliwości skierowany do Parlamentu, Portuguese Ombudsman. Report to the Parliament 2015, Lisbon 2016, s. 21 (http://www. provedor-jus.pt/?idc=16\&idi=16385, dostęp: 27.08.2016 r.). 
nastąpił wzrost liczby spraw zakończonych naprawieniem szkód powstałych w wyniku naruszenia praw obywateli poprzez działanie organów administracji publicznej (39,2\% spraw w 2014 oraz 42,6\% spraw w 2015 r.). W 18 sprawach Rzecznik skierował do odpowiednich organów zalecenia. Co więcej, nastąpił spadek liczby spraw zakończonych oddaleniem skargi (38,6\% spraw w 2014 i 37,8\% spraw w 2015 r.) ${ }^{42}$, co może świadczyć o zwiększeniu świadomości społeczeństwa o zakresie działalności Rzecznika oraz sprawowanej przez niego ochrony praw i wolności.

\section{Podsumowanie}

Instytucja ombudsmana, którego podstawowym celem jest urzeczywistnianie podstawowych praw i wolności człowieka, jest koniecznym elementem każdego współczesnego demokratycznego państwa prawnego. Provedor de Justica stanowi w Portugalii podstawowy organ, którego zadaniem jest ochrona praw i wolności człowieka. Działalność Rzecznika Sprawiedliwości jest szczególnie istotna z punktu widzenia zabezpieczenia obywateli przed nadużyciami popełnianymi przez administrację publiczną. Instytucja ombudsmana istnieje już w Portugalii od 41 lat, a do dnia dzisiejszego funkcję swoją pełniło już dziewięciu Rzeczników.

Dane zawarte w sprawozdaniach skierowanych do Zgromadzenia Republiki obrazują w sposób wyczerpujący działalność Rzecznika Sprawiedliwości w Portugalii. $Z$ danych w nich zawartych wynika, że instytucja ta działa prężnie i corocznie zajmuje się rozpatrywaniem wielu wpływających skarg. Większość z nich dotyczy naruszeń z zakresu spraw związanych $z$ zabezpieczeniem społecznym, zatrudnieniem, podatkami oraz administracją wymiaru sprawiedliwości. Przychylić należy się jednak do stanowiska, iż obserwuje się obecnie trend do zmniejszania liczby postępowań prowadzonych przez ombudsmana. Portugalska literatura przedmiotu zwraca jednak

\footnotetext{
42 Raport Rzecznika Sprawiedliwości skierowany do Parlamentu, Portuguese Ombudsman. Report to the Parliament 2015, Lisbon 2016, s. 22 i n. (http:// www.provedor-jus.pt/?idc=16\&idi=16385, dostęp: 27.08.2016 r.).
} 
uwagę, że przyczyną takiego zjawiska jest ogólna sytuacja polityczna w kraju oraz stabilność instytucji demokratycznych.

\section{STRESZCZENIE}

Provedor de Justiça, czyli ochrona praw obywatela

z punktu widzenia doświadczeń portugalskich

Podstawowym zadaniem ombudsmana jest urzeczywistnianie podstawowych praw i wolności człowieka. Istotna funkcja, którą pełni, sprawia, że jest to instytucja niezbędna w każdym współczesnym państwie demokratycznym. Rzecznik Sprawiedliwości stanowi w Portugalii podstawowy organ, którego zadaniem jest ochrona praw i wolności człowieka. Działalność Rzecznika jest szczególnie istotna $z$ punktu widzenia zabezpieczenia obywateli przed nadużyciami popełnianymi przez administrację publiczną. Instytucja ombudsmana istnieje już w Portugalii od 41 lat i nadal cieszy się istotnym znaczeniem w państwie. Celem niniejszego artykułu jest przybliżenie wprowadzonej w Republice Portugalii instytucji ombudsmana, jego kompetencji oraz pozycji ustrojowej, przy szczególnym uwzględnieniu przysługujących mu środków ochrony praw i wolności obywateli w oparciu o obowiązujące obecnie akty prawne. Niniejsza praca zwraca również szczególną uwagę na działalność Rzecznika oraz skuteczność gwarantowanej przez niego ochrony praw przyznanych portugalskim obywatelom.

Słowa kluczowe: Rzecznik Praw Obywatelskich; Rzecznik Sprawiedliwości; ochrona praw obywatelskich

\section{SUMMARY}

Provedor de Justiça - the protection of citizens' rights and freedoms from the point of view of Portuguese experiences

The main task of the Ombudsman is protection of basic human rights and freedoms. The essential function, which he fulfills, makes this institution indispensable in any modern democratic country. Spokesman of Justice is the main body in Portugal, whose task is to protect human rights and freedoms. The activities of the Ombudsman are particularly important when it comes to protection against abuse by public administration. Ombudsman's institution has already existed in Portugal for 41 years and still 
plays an important role. The purpose of this article is to discuss institution of Ombudsman, introduced in the Republic of Portugal, it's competences and position in the country, with putting particular attention to means of protection of the rights and freedoms of citizens, which he exercises on the basis of applicable law. This article puts also special attention to the activities of the Ombudsman and their efficiency in protection of the rights granted to Portuguese nationals.

Keywords: Ombudsman; Spokesman of Justice; protection of civil rights

\section{BIBLIOGRAFIA}

Banaszak B., Porównawcze prawo konstytucyjne wspótczesnych państw demokratycznych, Warszawa 2012.

Banaszak N., Rzecznik Praw Obywatelskich wobec administracji samorzadu terytorialnego, Wrocław 2013.

Deryng A., Rzecznik Praw Obywatelskich jako wnioskodawca $w$ postępowaniu przed Trybunałem Konstytucyjnym, Warszawa 2014.

Domańska A., Pozycja ustrojowo-prawna Rzecznika Praw Obywatelskich, Łódź 2012.

Garlicki L., Ewolucja instytucji Rzecznika Praw Obywatelskich (ombudsmana) $w$ świecie wspótczesnym, w: Rzecznik Praw Obywatelskich, red. L. Garlicki, Warszawa 1989.

Łabno-Jabłońska A., Rzecznik Sprawiedliwości w Portugalii, w: Rzecznik Praw Obywatelskich, red. L. Garlicki, Warszawa 1989.

Łabno-Jabłońska A., Iberyjska droga do demokracji. Studium prawno-konstytucyjne, Warszawa 1996.

Łabno-Jabłońska A., Od rządów autorytarnych do demokracji parlamentarnej. Rewolucja portugalska 1974-1976, Katowice 1989.

Malinowska I., Rzecznik Praw Obywatelskich $w$ systemie ochrony praw i wolności $w$ Polsce, Warszawa 2007.

Miranda J., Kownacki P., Konstytucja Portugalii, Warszawa 2000.

Ombudsmani krajowi. Zbiór regulacji prawnych, red. J. Pisarczyk, Warszawa 2005.

Prawo konstytucyjne, red. Witkowski Z., Bień-Kacała A., Toruń 2015.

Reif L.C., The ombudsman, good governance and the international human rights system, Leiden 2013.

Righting wrongs. The ombudsman in six continents, red. R. Gregory, P. Giddings, Amsterdam 2000. 
